\title{
The Kanamari Body-Owner. Predation and Feeding in Western Amazonia
}

Luiz Costa

\section{OpenEdition}

\section{Journals}

Electronic version

URL: https://journals.openedition.org/jsa/11332

DOI: 10.4000/jsa.11332

ISSN: 1957-7842

\section{Publisher}

Société des américanistes

\section{Printed version}

Date of publication: 5 June 2010

Number of pages: 169-192

ISSN: 0037-9174

\section{Electronic reference}

Luiz Costa, "The Kanamari Body-Owner. Predation and Feeding in Western Amazonia", Journal de la Société des américanistes [Online], 96-1 | 2010, Online since 10 December 2014, connection on 03 September 2022. URL: http://journals.openedition.org/jsa/11332 ; DOI: https://doi.org/10.4000/jsa 11332 


\title{
THE KANAMARI BODY-OWNER. PREDATION AND FEEDING IN WESTERN AMAZONIA
}

\author{
Luiz COSTA *
}

This article is an ethnography of the Kanamari concept of -warah, a word that simultaneously means " living body », " owner » and " chief ». It aims to establish the relationship between these meanings through a focus on the replication of the -warah at different scales: from the body of individual persons, through the village chief, into the chief of a river basin. It is argued that each of these positions implies the capacity to familiarize its inverse through acts of feeding. In this way, and respectively, the soul, co-resident villagers and the people of a subgroup are made into component parts of their -warah in a process that is analogous to acts of familiarization that have been described for other parts of Amazonia. [Key words: Kanamari, Western Amazonia, predation, familiarization, body.]

Le corps-maître kanamari. Prédation et alimentation en Amazonie occidentale. Cet article propose une description ethnographique du concept kanamari de - warah, qui signifie, simultanément, " corps vivant », " maître » et " chef ». Nous tentons d'établir ici une relation entre les différentes acceptions de ce terme, en montrant que le concept ne fait que se répliquer à différentes échelles: celle du corps des individus, celle des chefs de village et jusqu'à celle des chefs d'un bassin hydrographique. Chacune de ces positions implique la capacité à familiariser son contraire à travers l'alimentation. Ainsi l'âme, les co-résidents et les membres d'un sous-groupe sont intégrés à leur -warah respectif selon un processus analogue à celui des actes de familiarisation déjà décrits dans d'autres sociétés amazoniennes. [Mots-clés: Kanamari, Amazonie occidentale, prédation, familiarisation, corps.]

O corpo-dono kanamari. Predação e alimentação na Amazônia ocidental. Este artigo é uma etnografia do conceito kanamari de -warah, que significa, simultaneamente, " corpo vivo », " dono » e " chefe ». Busco estabelecer a relação entre estes significados através de um foco na replicação do -warah em diferentes escalas: do corpo de pessoas individuais, passando pelos chefes de aldeia, ao chefe de uma bacia hidrográfica.

* Associate Professor at the Instituto de Filosofia e Ciências Sociais da Universidade Federal do Rio de Janeiro, Largo de Sào Francisco 1, Sala 412, 20051-070, Rio de Janeiro, R. J., Brazil [luizcosta10@gmail.com].

Journal de la Société des Américanistes, 2010, 96-1, pp. 169-192. O Société des Américanistes. 
Argumento que cada uma dessas posições implica a capacidade de familiarizar o seu inverso através da alimentação. Assim, e respectivamente, a alma, os co-residentes e as pessoas de um subgrupo são feitos componentes de seu -warah, num processo análogo aos atos de familiarização que foram descritos em outras partes da Amazônia. [Palavras chave: Kanamari, Amazônia ocidental, predação, familiarização, corpo.]

This article is a study of an Amazonian relationship of "mastery » or " ownership ». Relationships of this type are widespread in lowland South America and there is great variation in their scope and form. They generally involve an asymmetry in which one term of the relation, the " master ", is often seen to encompass or contain his creatures or followers, whom he protects and cares for (see Fausto 2008, pp. 333-335). In this text, I will focus on the figure of the master as a container of others, as a singularity that detains a multiplicity within his person. My discussion will concern the ethnography of the Katukinaspeaking Kanamari, an Amerindian people who live in the vicinity of the middle Juruá River, in the Brazilian part of Western Amazonia ' ${ }^{1}$ I will show how the master is constituted and how his relationship to a multiplicity is articulated. There are two factors that make the Kanamari a particularly interesting case study for relationships of mastery: first, the concept of the owner-master pervades all aspects of their socio-cosmology; second, the Kanamari word that indexes this relationship has a meaning that makes it differ from other, analogous terms that are often rendered as « master » or " owner ».

The Kanamari word in question is -warah, which, as I quickly learned, means " owner ». I first heard it used to define ownership of material things, but it soon became clear that the word was also used to refer to the chief. There is nothing particularly exceptional about this and there are numerous examples in Amazonia where mastery over people and ownership of things merge or determine each other: the Carib words oto (Kuikuro) and entu (Trio) mean both owner of things and of the village, coming thus to mean chief (Heckenberger 2005; Brightman 2007, pp. 83-84); while Panoan-speakers call their chiefs by words that mean " master » and also indicate ownership of material things, such as $i b u$ in Kaxinawa or igbu in Matis (McCallum 2001, pp. 33, 111-112; Erikson 1996, pp. 180-181). In this context, the Kanamari-warah is simply another interesting example of a widespread feature of lowland South American societies.

The situation became more complex, however, when I learned that -warah also means "living body ", and that it is used to refer to the bodies of humans, animals and some plants. The first time that I heard the word-warah used in this way was in a conversation about chieftaincy with a Kanamari man called Poroya. I was asking about some of the characteristics of the Kanamari chiefs of the past when I questioned him concerning those chiefs' bodies, as I recalled from earlier talks that these chiefs were always described as being "large people » (tukuna 
nyanim). I thus asked about the chief's -boroh. The Kanamari were always very polite about my linguistic mistakes, but the question I was asking Poroya was not immediately intelligible to him. I therefore asked him the question in Portuguese, since Poroya spoke it better than other Kanamari. He explained to me that my question was wrong because the word -boroh means « corpse », not " body ", and that the correct way to refer to the (living) body is -warah. Realizing my difficulty in understanding this, he explained to me in Portuguese that « our body is our owner and our chief ». It is impossible to say this phrase, as it is, in the Kanamari language. The order of the statement is furthermore interchangeable, such that it would be equally correct to assert that « our chief is our body and our owner », for example.

Poroya's clarification, however, is only a fraction of the story, for I later understood that the chief and the living body are but some of the figures that the concept of -warah contains. It is impossible, within the scope of this article, to explore all of the meanings of this word, and I will therefore take up the challenge presented in my conversation with Poroya and limit myself to two points. First, I will establish the relationship between chieftaincy and living human bodies by describing the constitution of both. In this sense, although I will briefly review how the word -warah defines ownership of what we might term « objects », my argument will focus on the ownership of people. Secondly, in so doing, I will reveal what may be called the fractality, or self-similarity, of the -warah - that is, according to Gell (1998, p. 137), its re-occurrence at different levels of magnification and minification, traversing inter-personal and intra-personal relations (Viveiros de Castro 2001, p. 31) ${ }^{2}$. In the conclusion I will briefly explore one of the ways that the -warah extrapolates from the chief, defining a world that pre-exists him, and which therefore determines his own body. From this perspective, we shall see, the chief and the living body are a transformation of relationships that replicate themselves throughout the cosmos.

\section{BODY AND OWNER}

My argument will be ethnographic. I will show, through an analysis of Kanamari chieftaincy and the body, how the word -warah can refer to both the living body and the owner. Before doing so, however, I would like to clarify some of the contexts in which we might gloss, in English, the word -warah as either " body " or " owner ".

The word -warah implies a relation, such that a -warah will always be of something, someone or some people, and there is no way to refer to an unspecific -warah that is independent of a subject with a form. In this sense, wiri-warah, for example, can mean " peccary-body ", and it would therefore refer 
to the living body of any peccary, as opposed to, say, a tukuna-warah, " personbody " (i.e. the body of any living person). In the case of humans, a name can sometimes take the place of the class. Poroya-warah can therefore be glossed as " Poroya's body » or, more accurately, " Poroya-body », and, in these cases, the Kanamari often translate the word -warah into the Portuguese corpo, «body ».

In other contexts, however, they render the word -warah by the Portuguese dono, " owner » or " master ». Although it can be used as a verb, in a manner similar to the English verbs "to own » or "to have », my main concern is with its use as a noun or noun phrase. In this way, a question such as " who tied this canoe? » can be answered as $a$-warah, « its owner [did so]». In some cases, -warah can denote exclusive ownership of a class, such as in myth, in which Deer is said to be the "tobacco owner » (oba-warah) and all other beings have to go to him to obtain it. It is in an analogous sense, as I have said, that the word comes to mean "chief ", who is thus a "person-master» or "personowner» (tukuna-warah $)^{3}$.

The translations of -warah as either " body » or " owner », however, only work as contextual glosses, and even then they only express partial meanings. This should be clear through the example of tukuna-warah. When referring to the body, I glossed this expression as "person-body", and when discussing the chief as "person-owner ». One Kanamari, a Portuguese-speaking school teacher, has suggested that sometimes -warah should be translated as " body ", other times as " owner ", depending on context. Most, when directly asked how to translate -warah, say that it means " body and owner ». What this indicates is that it is not possible, under these circumstances, to distinguish between the body of a person and his or her material or human possessions. Thus the name of a person followed by -warah designates not only that person's body, but also, in the case of chiefs, all those people who call that person $i$-warah ( " my chief »), as well as all of the belongings of the person whose name makes up the noun phrase "X-warah» and those of the people who belong to him. Poroya, for example, is a chief, and Poroya-warah can therefore mean, simultaneously, Poroya, the people who co-reside with him, those things that they own and the place where they live. Indeed, as we will see shortly, the name of a chief followed by -warah is synonymous with the village and the stream in which it is established.

Following this translation, then, I suggest that all nominal instances of the word -warah be rendered as " body-owner ». Even if, for linguistic or practical reasons, one were to posit differential glosses for the term, this would make little sense ethnographically. This is so because every body-owner is predicated on the same relationship, replicated at different scales. Briefly, the body-owner can be defined as a stable social form in relation to a generic, unspecific mobility that is linked to the soul. The remainder of the article will be a demonstration of this definition. 


\section{THE BODY-OWNER AND THE RIVER BASIN}

An understanding of the body-owner within the context with which I am concerned requires that certain formal aspects of Kanamari social organization be made clear. Kanamari is not a traditional auto-denomination. The most comprehensive term for all speakers of Katukina-languages is tukuna, which means " person ». As is common in Amazonia, tukuna does not denote humanity as a natural species, but rather acts as a personal pronoun, registering the point of view of a subject (Viveiros de Castro 1998, p. 476). For the Kanamari of today, all Katukina-speaking peoples are tukuna.

The main division that the Kanamari recognize among tukuna is that between the members of different kin units that I will call « subgroups ». These are named, endogamous and geographically circumscribed to tributaries of both banks of the Juruá River, mostly to those of its middle course. Their names are invariably formed by that of an animal followed by the suffix -dyapa. Each -dyapa inhabits a river basin that is a tributary of the Juruá, and they are therefore separated over land by the watershed between them, while being connected by the Juruá river's main channel ${ }^{4}$.

Each subgroup defines and exhausts a given Ego's universe of «kin » (-wihnim). In other words, one's kin are all the members of the subgroup and only these people are one's kin. Since subgroups are situated on specific river basins the names of the subgroups and the main tributary of these basins are synonymous, particularly when the word -warah is suffixed to the river's name. The following schematic map (Figure 1) illustrates the settlement pattern of the Curassow-dyapa, who are also known as Komaronhu-warah, since this is the name of the tributary of the Juruá in which they live. The map depicts the settlement pattern as it was in the early 1920's ${ }^{5}$.

As the map shows, there are important distinctions that exist within the subgroup, associated to the spatial layout of settlements along the river basin. One settlement, called Barreiro, was on the Komaronhu itself. This settlement was a longhouse (hak nyanim), surrounded by its large garden (baohmim nyanim) and fallows (baohnim padya, lit: « empty garden »). The longhouse is the place of the subgroup chief, the body-owner of the whole subgroup and the only person to reside with his family in the vicinity of the longhouse for the whole of the year. This chief is sometimes called the " longhouse-body-owner " (haknyanim-warah) and his person is synonymous with the subgroup, in much the same way that the main channel of a tributary is. His name, therefore, followed by -warah, is a third way of referring to the subgroup. In the $1920^{\prime} \mathrm{s}$, for example, the body-owner of the Curassow-dyapa, and therefore the year-long resident of Barreiro, was a man called Kaninana. The expression Kaninana-warah was thus a further way of referring to the kin unit that was the Curassow-dyapa of the Komaronhu River. 


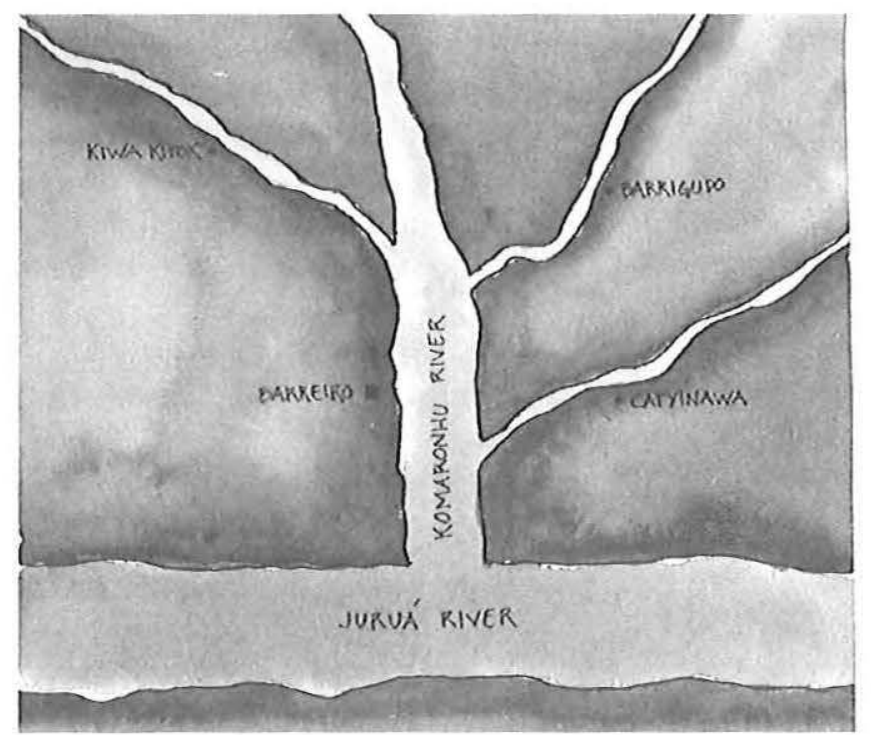

Fig. 1 - Schematic map of the Komaronhu river of the Curassow-dyapa, c. 1920.

Each of the smaller streams that flows into the Komaronhu - called igarapés in Portuguese and wahdin in Kanamari-are also settled ${ }^{6}$. These have no longhouse, but instead more or less ephemeral villages that undergo regular changes, both in their composition and in their situation. In spite of these rearrangements, non-longhouse communities are always built on the streams that flow into a subgroup's tributary and never on the tributary itself. There is no Kanamari word for what I call "village " and each one is often named after the stream in which it is established. There are, furthermore, two ways of referring to the people who live in them: they are either called by the name of the stream/village followed by -warah - as, for example, Kiwa Kitok-warah -, or else by the name of their chief, whom I will call the " village chief », followed by the word-warah.

The hydrological and residential distinctions within a river basin also introduce differences between qualities of kin. Thus all of the people who co-reside for a part of the year with a village chief in a stream are " true kin » (-wihmim tam) to each other. They will call the village chief « my body-owner » ( $i$-warah), and he will refer to them as «my people» (atya tukuna). Any two people who, at a given moment, reside in different streams within the same river basin are, ideally, " distant kin » (-wihnim parara, also: "spread out kin »). These people will call different village chiefs "my body-owner». Marriage, in fact, should occur between these distant kin; that is, they should be village exogamous but 
endogamous to the subgroup. The distinction between true and distant always remains internal to the subgroup, and therefore to the category of kin,-wilmim. People who live in separate villages/streams may be distant kin, but they are still kin precisely because, within the river basin, there is a longhouse on the tributary that belongs to a subgroup chief whom they all call "my body-owner». The subgroup chief, for his part, calls all of the people of the subgroup " my kin » (i-wihnim) or else « my people» (atya tukuna).

The kin distinctions thus replicate the dendritic pattern of the river basin ${ }^{7}$. The name of a tributary of the Juruá is co-extensive with a subgroup kin unit, and it expresses the subgroup as a whole. The longhouse, built on that river, effaces distinctions internal to the river basin by converging them into the subgroup chief, whose name contains the different villages; just as, in a hydrological key, the river joins all of the streams into a single unit. However, the river basin/subgroup body-owner conceals within it the hydrological and kinship distinctions that a focus on the streams reveals. These distinctions thus fraction the one tributary into many streams, and the kin unit into aggregates of true and distant kin, resulting in a series of partial perspectives on a single unit. This is so because the name of each village chief (or stream) followed by -warah only contains those residents of the river basin who live with him (on the same stream), while that of the subgroup chief contains its totality.

So a name followed by -warah always denotes a singular entity, but one that is multiply constituted, and whose constituent parts can be revealed through its detotalization (Gell 1999, p. 50). Anyone or anything that is a body-owner will, potentially, be a body-owner to a number of people and things, singularizing this multiplicity. I will now analyze the constitution of this singularity in light of the relationship with which I am concerned - namely that between corporeal stability and the mobility of the soul. For the sake of clarity, I will describe the bodyowner in three intervals, that I will label « body », « village chief » and « subgroup chief ", thus keeping to the exposition of social organization that I have just presented. It must be remembered, however, that these labels substitute for the word -warah, and that they are therefore shorthand designations whose complexity will be revealed through ethnographic analysis.

\section{THE BODY}

For the Kanamari, the living bodies of humans and animals derive from a generic soul, -ikonamin. Like the term -warah, that for soul also needs to be prefixed by a name or a pronoun. However, if this makes the two terms linguistically analogous, there is nonetheless an important difference between them. While the -warah points to the form of a living being - that form being indexed by its prefix -, the most unspecific and therefore comprehensive way of referring to 
the soul is tukuna-ikonanin, "person-soul ». The inverse, we have seen, is not the case: there is no unspecific way of referring to the body, which always implies a minimal form predicated on the different types of relations that made it. Personbody-owner thus refers to the bodies of Katukina-speaking human beings, but not to a generic body; while person-soul, on the other hand, defines a potential of all living beings.

Even if, to some extent, the soul always remains unspecific, the process of imbuing it with a bodily form acts upon it. In order to understand how this occurs, we must briefly contrast the relationship between soul and body during birth, in growth and after death. For the Kanamari, the soul is intimately linked to blood (mimi). Indeed, the Kanamari see blood as the visible or sensible manifestation of the soul, and one man explained to me that our soul is « truly our blood " (tyo-mimi ninbak). Newborn children are beings of almost pure blood, having only an incipient body. This body is so incipient that blood pours out of it, as is evident during the mother's post-partum haemorrhaging. The Kanamari say that the blood that seeps from the mother after she gives birth is the child's, whose " unripe » (parah tu) body is unable to contain it. For this reason, blood flows from the fotus into the mother while she is pregnant, and out of her after she gives birth. Post-partum restrictions act to ensure the dissipation of this blood that is external to the child, while allowing the blood in the child to ripen into a human body. The clearest indication of this process is growth, which is said to result as blood is pumped through the body. As this occurs, the child's person-soul gradually becomes associated with her body, a process that effaces some of the generic quality of the soul by prefixing it with the form of the emerging body: it will now be X-ikonanin, the soul of a subject with a body, and not just a person-soul. It is useful here to adopt Fausto's distinction between the soul as a "general and indeterminate virtuality of existence " and its destiny, as it becomes linked "with what the person becomes... » (Fausto 2007, p. 509, footnote 22). If the person-soul is a universal quality of living beings, the prefixed soul has been made into a specific body, which can manifest a specific soul.

More than a common soul for everyone, then, person-soul seems to point to a meta-soul; to a quality of existence that retains the potential to adopt a multitude of bodies (see Viveiros de Castro 2001, pp. 33-34; Vilaça 2005, p. 453). For the Kanamari, the soul is pre-social at birth, generic, formless and unrelated to the living; but at death it has a form, dictated by its (former) body's growth and the memories of what was done to it. What lies in-between is the process of kinship, and the specification of the person-soul through a single body depends on the care of close kin, particularly as they feed the child. After death, the memory of being fed attaches the soul to those bodies who remain living. As the Kanamari say, the soul now remembers. The word for « to remember », -wunimdak, literally means « desire continues along » (i.e. continues to exist). Since the soul continues 
to desire, it will often be attracted to the living bodies of former kin, causing it to linger in their vicinity.

In fact, this mobility of the soul is one of its defining characteristics. Souls, be these manifested in perinatal or post mortem moments, display two invariant traits: first, they are characterized by their propensity for movement and volatility - but only when absent or otherwise displaced from a body -, second, and at the same time, the movement of souls always occurs towards a body or bodies. These are default conditions that have a series of more or less disastrous consequences for the living. We have seen that, after a death, the movement of the soul (that used to be a body) is linked to its desire for and memory of specific kin. Generic person-souls (who are not yet bodies), however, are content with any living body. This desire is sometimes manifested prior to birth, as an interdiction on young children whose bodies are beginning to take specific form: they should stay away from pregnant women, lest the fotus " tug " (nikikman) at their hair, making them go bald and, as a consequence, ensuring that at birth the newborn will have strands of " shallow hair » (ki-pui tinim $t i$ ), while the living infant grows ill. Hair is a potent emblem of the body, and healthy, black hair indicates a « beautiful» (bak) body that has been made in proper ways, with the correct prescriptions being observed at crucial moments in life. Concurrently, baldness and grey hair indicate the corruption of the body through an idle, worthless life, one that is miserly and angry. In other words, a life that is more becoming of a soul than a human body. Indeed, the Kanamari often explain that young children, who are mostly soul, are miserly and greedy, demanding a large share of their parents' attention, or wanting food only for themselves, and that they must therefore be taught to behave properly. The knowledge of proper behaviour is concomitant to growth, and to the imposition of a human body on a soul.

The miserly, greedy and angry qualities of the soul, along with its inherent mobility, lead the Kanamari to associate it with a predatory capacity that is explicitly linked to the jaguar. This perhaps better qualifies the generic soul as an omnipresence that expresses movement and as a potential that always lurks in the vicinity of a body's stability. The danger of these souls is precisely their imposition upon living bodies, which results invariably in the predation of the latter and possibly in their demise. This is why the process of human kinship must ensure that souls are made stable and sociable, and that by being made stable they are made inactive and inert, a component part of bodies.

The revelation of a fully human body thus depends on an attenuation of the mobile, predatory and transformative properties of the soul and, consequently, on the ability of co-resident kin to curb this movement through relations of kinship and feeding that constitute a generic person-soul as a specific personbody ${ }^{8}$. I believe that we can here recuperate the other meaning of the Kanamari word -warah: a body should be made the master of the soul because it situates the soul, reduces its activity and volatility, renders it an object in relation to 
an active and healthy body. We know, however, that -warah refers not only to the living body, but also to the chief. The question, then, is what role does the chief, a higher-scale body, play in containing erratic mobility and antisocial behaviour?

\section{VILLAGE CHIEFS}

The Kanamari always spend some of the year in a village, situated on the streams of their subgroup's tributary. Being a member of a village means three things: first, that everyone who is of the same village live, for at least some of the year, spatially close to each other in the same stream; second, that all of these people consider the others who live with them to be «true kin " (-wihnim tam); and, third, that all of these true kin call a single co-resident man " my bodyowner ». This man is the village chief and, from a Kanamari perspective, he is the condition for the two other definitions of the village.

Village chiefs are much like chiefs and headmen in other parts of Amazonia, and their villages are similar to what has been described throughout the region (e.g. Rivière 1984). Kanamari post-marital residence is preferentially uxorilocal, and villages will often be constituted by a chief, his wife, their daughters, the latter's husbands, as well as by the young children of all of these. Alternatively, some villages are composed of a nucleus of sisters and the men whom they marry - co-affines who, after the period of brideservice, decide to continue to live together. Occasionally, two or more small settlements co-exist within a single stream at a short distance from each other, but in these cases they do not, normally, comprise separate villages, since the residents of both settlements remain true kin because they recognize the same village chief.

If village chiefs are almost always fathers-in-law to a host of young, in-marrying men, Kanamari explanations of villages tend to downplay this fact. The village chief is instead said to be " he who starts the garden " (baohmim makoni-yan), which means that he will be the one to select the site of the future village and organize work towards clearing the garden. The choice of a suitable plot is considered to be a hallmark of the quality that the Kanamari call «knowing the land» (ityonim-tikok). This implies not only knowledge of the forest and, consequently, the ability to identify appropriate garden sites, but also capacities that the Kanamari consider conducive to this knowledge, such as moderation, generosity and calmness. People who know the land are those with " beautiful speech/language » (koni-baknim), capable of dissipating the " angry speech/language » (koni-noknim) that sometimes emerges among people who work together. In fact, starting a garden (and hence a village) is intimately linked to speech, since « to start », makoni, literally means « to speak at a [given] place »; i.e. to say that a garden will be made there. 
The Kanamari stress that everyone who works in the garden, including those who have to - such as a future chief's sons-in-law -, and those who chose to do so - such as his brothers and brothers-in-law - all work " together », da-wihnim. The word -wihnim, we have seen, means kin and the prefix da-indicates that an action is carried out or a state is attained for a short amount of time, or until the focus of one's actions shift. "To sleep », for example, is kitan, but « to take a nap » is da-kitan; " to give » is nuhuk, but « to give before going somewhere else » and « to lend » is da-nuhuk. So " together » literally means " to be kin for an amount of time » or " to be kin before going somewhere else », and it situates togetherness, including collective gardening, as a moment in the production of kinship. Doing things da-wihmim makes people into kin for the duration of the act, but it does not necessarily undo kinship at its conclusion. If people start to enjoy doing things together, they may chose to do so often, taking up residence with the village chief and remaining or becoming true kin to each other. Their continued upkeep of the garden ensures that they are working da-wihnim tam, " truly together », but also, and literally, " as true kin for the time being ».

As the above expression suggests, being true kin to the same people is not a fixed, immutable state. Although one will always have true kin, these need not be the same people throughout one's life. As is common in Amazonia, kinship is largely performative, being based on commensality and the proximity of living together more than on genealogical relationships (Gow 1991; Vilaça 2002). In this sense, it is spatial proximity that defines kinship, and if those who live within a river basin are kin, those who co-reside in the same village become true kin. Villages, however, in spite of the efforts of the chief, are relatively ephemeral and readily re-arranged, its members redistributing themselves among other villages within their river basin and making themselves true kin to other people. The death of the chief, furthermore, often means the disbandment of a true kin unit, and the spreading out of people. The term I gloss as « to spread out » is parara. It is the same term that the Kanamari use to refer to distant kin (-wihnim parara): that is, those people who, although still kin (-wihnim), do not co-reside in the same stream, and who therefore call a different village chief « my body-owner ».

What, then, keeps the village together? The Kanamari consistently give two answers to this, which are really only one: the chief's generosity and his ability to feed everyone who lives with him. This feeding is expressed as an initiative towards garden making, as we have seen, and also in the chief's role as a distributor of raw meat, brought to his house, butchered by his wife and shared with co-residents (Costa 2007, pp. 176-179). These acts, however, are not paradigmatic moments of feeding, but rather events that point to its underlying condition. A thorough consideration of feeding requires that we look at the body-owner that contains the different villages, and their chiefs, within him. 


\section{SUBGROUP CHIEF}

Even if villages are ephemeral, the move towards other villages or the establishment of new ones are nonetheless limited by the two constraints that I made explicit earlier: all villages must exist in the streams that flow into a tributary of the Juruá, and they must be situated in the subgroup's river basin. The main channel of the tributary is thereby reserved for the longhouse.

In order to be direct, I will focus on what the Kanamari consistently say is the subgroup chief's main virtue: the fact that he feeds everyone in the subgroup. This foregrounds all of the reasons for villages travelling towards the longhouse and a discussion of it will allow us to link the subgroup body-owner to those of the village and the individual person. The Kanamari word that I translate as " to feed " is ayuh-man, which literally means " to make the need » or " to make the necessity ». The verb man means " to make » and ayuh refers to a mechanical need or craving; ayuh-dok, for example, is " to need to defecate ". Ayuh-man implies the almost absolute dependency of the person that is being fed on whosoever is doing the feeding. Through feeding, the subgroup chief «takes care » (tokodo) of his people by ensuring that they remain in the river basin 9 . I should stress that what I call "feeding " is slightly different from " eating " (wa-pu) or " commensality » (da-wihnim-pu, literally to « eat together as kin/for a while »). I suspect that these two actions are often conflated in ethnographies and, in the Kanamari case at least, commensality - and the consequent production of kinship - is only possible if there is someone who feeds, or makes the necessity, in the first place. Feeding can either be giving or redistributing food so as to establish villages of true kin, or else it is making food available to all kin. If the former definition of feeding is clearly exemplified in the village chief, the latter meaning is a condition of the subgroup chief.

Three factors make the longhouse a place where food is abundant. The first is the fact that it is surrounded by a "large garden " (baohnim nyanim). These are more extensive than those of the village, because everyone who visits the longhouse helps to work together towards making it. The carrying out of this work, and the consumption of its products, is one of the reasons for gathering around the longhouse. The productivity of the garden is therefore said to be « unending » or " infinite " (hawak nyo'imtu), and its permanence contrasts with the ephemerality of village sites. At the same time, the large garden acts as the guarantee for the smaller gardens of each village, since many of the crops that are grown in the latter are selected from varieties in the former. A village chief who has just chosen a new village and garden site will spend much time in the longhouse with his people, since they will depend on the large garden's continuing productivity to feed themselves while their own plots remain unproductive and while they select the crop varieties they will plant in their new village. The longhouse's large 
garden is thus the condition for the re-arranging of villages within the river basin, since it ensures that, if the latter disintegrate, people will not starve. They are always able to move to the longhouse and to depend on its garden until a new village is established.

The second source of abundance of food is the large fallow that surrounds the garden. These fallows are tracts of secondary forests that result from the abandoned gardens and longhouses of generations of Kanamari who formerly lived in the river basin. They are remarkable for the variety and fertility of their palm species. Their continuing existence and productivity results from regular upkeep, and this ensures that, like the large gardens, they are also unending (see also Rival 2002).

Finally, it is in the longhouse that the Pidah-pa increase ritual is held. Pidah-pa literally means «Jaguar-becoming ». According to the Kanamari, the main reason for holding the ritual is to find game. They explained to me that the performance of the ritual guarantees the presence of game animals in a river basin and that, concurrently, failure to perform the ritual on a yearly basis results in the disappearance of game. A Jaguar-becoming cannot occur without the presence of the subgroup chief: not only is it within his longhouse that it must occur; it is also his knowledge of the "Jaguar-songs » that enables it, and therefore ensures the availability of game meat.

The subgroup chief feeds everyone in the subgroup by making food available to them and ensuring its continuity. If a village chief's death means the end of the village, the subgroup chief's death means that a suitable successor needs to be found, lest the subgroup cease to exist and its members scatter. The term that I translate as « to scatter » is ino-na, and it results, in effect, in an unmaking of the broad category of kinship (-wihmim) that makes up the subgroup. Scattering after the death of a subgroup chief takes people away from their river basins and towards others, where they live with, and are fed by, another subgroup chief, thereby making themselves into people of that subgroup, kin to those who should, ideally, have remained non-kin (Costa 2007, pp. 68-69). It is therefore different from the spread out (-parara) relationship that characterizes kinship between people of the same subgroup who live in different villages. The latter remain kin insofar as they call the same subgroup chief " our body-owner». They may therefore spread out, so long as the subgroup chief contains their movement to a river basin through feeding. The subgroup chief is thus the subgroup's sociocentric horizon, the body-owner who cancels any differences internal to it, and the summation of true and distant kin.

\section{FAMILIARIZING SOULS}

The collective unit that results is a machine for making related humans out of soul, and for situating these humans in river basins. To ensure the placement of 
humanity, the subgroup body fractions into villages, that further fraction into individual bodies. In the same way that the body is made out of a mobile, predatory soul, so too are the Kanamari unanimous about the state of humanity without chiefs: people move constantly and erratically, never staying put, and they act in angry, inhuman ways, fighting with each other. They become, as some Kanamari told me, worthless (-dyaba). It can thus be said that individual body-owners, without higher-order body-owners, are fearful creatures, which relate to each other as souls. Viveiros de Castro (2001, p. 42, footnote 24) has said of Amazonian peoples in general that « the body connects (and collects) kin, the soul separates them into singular persons ». The Kanamari have developed this observation to its logical conclusion since, for them, singular persons are souls, and only body-owners connect and collect them into human persons. What guarantees kinship among humans is that the body-owner replicate itself throughout the river basin, just as the hydrology of each tributary repeats itself at different scales.

Furthermore, the vector for integrating the different intervals of the bodyowner is a relationship of feeding - of making the necessity of people. In other words, by satisfying the necessity of others, one becomes their master and owns them as components of a body. This introduces an asymmetry, for the bodyowner occupies the subject position, while those who are " his people » or " his soul » occupy the object pole ${ }^{10}$. It is for this reason that the name of a subgroup chief followed by -warah is a way of referring to all of the people of his subgroup. His body conceals and contains them, and his position as body-owner conceptually dissolves the differences internal to the subgroup and its members, who, in relation to him, appear as objects. This is not a given relationship, and it has to be created through feeding. What is given is its inverse: the souls' predatory potential, present in the world in a generic state and common to most species, needs to be reduced by the imposition of layers of body-owners.

Feeding is hence a means for transforming a generic, predatory relation into one of kinship within the subgroup. In this way, it establishes a bond that is formally similar to the type of symbolic control that is generally called « familiarization » in the Amazonian literature (Fausto 1999). The body-owner contains and controls three aspects of bodilesness. First, it reduces mobility, preventing humans from reverting to souls, or kinship aggregates from spreading out or scattering. Second, it reduces the predatory potential of souls, or the worthless violence of chiefless people. Third, it contains the transformative capacity of souls (the ability to assume different bodies) and that of people, who remain of a subgroup and river basin and thereby cancel the possibility of kinship with people from other subgroups.

The capacity to contain mobility and curb predation through feeding is not exclusive to the examples I have been analyzing here. The shaman, for instance, is also the body-owner of the dyohko spirits that he has familiarized, and he stores 
them, reduced to the form of a resinous gem, in a pouch that he keeps out of reach. The act of familiarizing a spirit is often described as a meeting in the forest in which the shaman offers the spirit tobacco powder, said to be its food, which it then accepts. This act makes it into a familiar, and the shaman remains the body-owner of his spirits so long as he continues feeding (ayuh man) it with tobacco powder, thereby imposing his own body upon it. While he does so, the spirit will call him $i$-warah, "my body-owner », and he will call it " my spirit » (atya dyohko). During my fieldwork, a shaman had his spirit-pouch stolen from him by another shaman who took it to a different river basin. Although the former shaman tried to call his spirits back to him, they would not come because the thief kept them well fed with abundant tobacco powder, thus remaining the body-owner of the spirits. The relationship between shaman and familiar is thus predicated on acts of feeding that make the feeder a master (-warah) and that which is fed a pet, and there is no shamanic control of spirits that is independent of it.

Unfamiliarized dyohko spirits, of which there are infinite quantities inhabiting the forest and the rivers, are dangerous predators. Their danger derives not only from the fatal illnesses that they cause, but also from the fact that they never stay still: they are everywhere, possess their own volition, and are capable of moving towards the river basins in which collective bodies of Kanamari situate themselves. The shamanic process of familiarizing these spirits is thus dependent on the instatement of a relationship of feeding that inverts a given predatory and mobile one and makes the shaman a master of the spirit. It is therefore analogous to the process by which the chiefs feed their people and the body imposes on the soul.

For the Kanamari, familiarization works by subsuming terms to a bodyowner through feeding, and it requires that one simultaneously account for relations that are internal to subgroups, villages and persons through the relationship between body and soul. Fausto (2007) has recently proposed that this relationship be readdressed through a study of its correlations and inversions, and this approach allows us to theoretically account for the different intervals of the body-owner. In Amazonia, he argues, persons are an amalgamation of activity and passivity, potential positions that are respectively linked to a predator and a prey capacity. In other words, persons are made from reiterated relationships between predatory (active or subject) components and prey (patient or object) ones. Although there is a tendency to link the soul to the predatory potential of the person and the body to his or her prey-part, Fausto stresses that the partition is orthogonal to that between body and soul, being irreducible to a global dualism. Furthermore, if the distinction between activity and passivity is internal to the person, it also characterizes relations between subjects who are an amalgam of these positions. As Fausto (2007, p. 513) states « when predatory interaction is established between two persons thus constituted, a 
metarelation is created in which one of them occupies the agent position and the other the patient position ".

This approach allows us to conceptualize the Kanamari body-owner in a way that accounts for both the replication of relationships at the intra- and interhuman levels and for the transformation of predatory relations into those of feeding. We have seen that for the Kanamari souls are associated with a default, omnipresent movement that, precisely, preys on their living bodies. What the Kanamari body-owner does, then, is to turn this condition of the world on its head by making the body-owner the active pole of a relationship of familiarization, thereby reducing the soul to inert object. In other words, the body-owner is created by erasing the activity of the soul. If souls and chiefless people represent predatory activity, the body-owner makes itself a figure of activity by feeding and containing what was previously an agent of predation, which in relation to it now becomes passive. This is not a simple redistribution of values between equal parts, for it involves the successful and successive making of body-owners from their inverse, through the recursive encompassment of volatility by form, of movement by fixedness, of predation by feeding.

However, there are two problems that remain, and need to be solved by way of a conclusion. The first is that, even if familiarization need not always be a corollary of predatory acts (Fausto 1999, p. 940) - that is, even if it need not be the result of warfare or hunting, for example -, it is nonetheless always a modality of predatory interaction, defined as « ... a highly abstract scheme predicated on the subsumption of a term of a relation ("other") by the other term ("self") ) (Taylor 2001, p. 55, footnote 2). Familiarization thereby emerges as a zero-limit to predation, a particular, non-violent way of actualizing its abstract scheme: « la familiarisation est non pas l'envers de la prédation, mais plutôt sa limite inférierure, une alternative à la dévoration littérale d'un des termes de la relation par l'autre, autrement dit une relation "positive" à des êtres (et entre des êtres) posés comme intrinsèquement cannibales » (Taylor 2000, p. 318). Yet even when it is nonviolent, a relationship of familiarization confers upon the term that retains volition a supplementary quality that often manifests itself as an accrued predatory capacity (Fausto 2007, p. 509). Returning to the Kanamari, what this means is that if the body-owner makes the predatory soul into an object through familiarization, then it does so by himself becoming a predator in the process of objectifying the soul.

The second problem is closely related to the first and concerns the self-similar scaling of the body-owner within each subgroup. Every singular -warah encompasses its converse multiplicity: the bodies of individuals objectify the soul; those of the village chief, the people who co-reside in a stream; and the sub-group chief stands for activity in contradistinction to the passivity of " his people ». Each of these relationships needs to be apprehended at the appropriate scale since any shift up the scale eclipses lower-order body-owners. From the perspective of a 
river basin, the subgroup chief contains its variability within his body. At this depth of field, the subgroup chief, as the most inclusive interval of the bodyowner, is the only body-owner in his river basin ${ }^{11}$. Within each subgroup, then, its chief is an arch-predator, and yet - and herein lies the paradox - he feeds those who live in his river basin, who in relation to his agency appear as passive recipients.

What, then, ensures this " positive " relation within the subgroup, and keeps the body-owner from preying on its component parts? Why does a subgroup chief feed, rather than feed on, the people of his subgroup?

\section{THE BODY-OWNER OF THE WORLD}

We saw that one of the ways that the chief becomes a feeder of the subgroup is by enabling a ritual called the Jaguar-becoming. Although I cannot here go into the details of this ritual (see Costa 2007, pp. 388-394), it begins to point us beyond each river basin. In fact, for the Kanamari, the internal structuring of the river basin described above derives directly from the bodies of certain mythical Jaguars. Kanamari mythology posits at its logical (if not its chronological) beginnings a series of Jaguars who were body-owners of the whole world. These Jaguars are characterized by two inter-related principles. First, they are pure predatory force - angry and miserly like the person-soul, they are the antithesis of the world that the Kanamari wish for themselves. Yet secondly, and at the same time, Jaguars are the body-owners of everything, and the whole world exists compressed in their bodies. The current world - including both its physical aspects and the social forms that compose it - is the result of the destruction of these primordial Jaguar bodies ${ }^{12}$.

As one example, we can briefly analyze one myth in which the Jaguar was a Fish-Body-Owner (dom-warah) who lived upriver with all the components of its body, the fish, which it ate. Ancestor Heron was reluctantly allowed to fish there, but his brothers-in-law were told by the Jaguar that they would be killed if they went. Hungry, since there were no fish anywhere else, they decide to go anyway and the Jaguar kills all of them. Ancestor Heron and the dead men's brothers kill the Jaguar in revenge, whereupon its body becomes many concentrations of rubber trees (Hevea brasiliensis), its falling leaves then transforming into piau fish and its seeds into pacu fish that swim down-river. Today, these fish only periodically return to the area around rubber trees to feed on the detritus that gathers in the river near it.

This is one of a series of myths that explain how aspects of the world were created from the body of these Jaguar masters ${ }^{13}$. In all of them, Jaguars contain a predatory food chain in which they feed on the components of their own bodies. After their death, their bodies unfold into aspects of landscape and their components flow from it, as movement down-river. No longer limited at all times to their 
body-owner, fish nonetheless still feed on their transformed body-owner's corpse. One continuous body is thus transformed into so many equivalent, discrete bodies, inverting the trophic order that the former contained: Jaguars are now multiple autotrophic biomes rather than singular (self-)consumers; primary producers who used to be apex predators.

The only geographical specification for these Jaguars whereabouts is that they lived in the Juruá. For the Kanamari, the Juruá is known as the Jaguar's River (Pidah nawa wah), and it pre-exists everything, including the creation of its tributaries. The Juruá is feared by the Kanamari for this very reason: mosquitoridden, endlessly long, overflowing with silty water and filled with dangerous dyohko spirits, the Juruá is also the body-owner of all its tributaries. At the same time, however, it is the place where the Kanamari's own bodies inevitably fail. The Kanamari are unanimous in affirming that, traditionally, there were no villages on the banks of the Juruá itself, but only, as we have seen, on its tributaries. The tributaries of the Juruá thus emerge as fragments of the continuous whole which is the Jaguar river and subgroups are units based on feeding because they make themselves against this predatory backdrop, just as landscape, in the form of concentrations of hevea trees, emerges from the destruction and subsequent transformation of Jaguars.

The movement of both hydrology and myth thus describes how predation gives way to feeding. This allows us to answer, at least in part, why the subgroup chief does not prey on his people ${ }^{14}$. The subgroup chief is situated at one remove from the Jaguar - in a tributary of its river -, being therefore a reduced version of this predatory potential. The cosmological and hydrological fractioning of Jaguars is a primordial transformation of predation into feeding, expressed as the carving of (many) consanguineal units out of a (single) unit of predatory violence. The subgroup chief is therefore a part of a world that antecedes him and extends beyond him, and it is against the backdrop and danger of this world that kinship is established (Viveiros de Castro 2001). Familiarization as feeding within the subgroup is therefore not opposed to predation beyond it. Instead, the two are articulated and embedded within a single cosmological matrix. For the Kanamari, familiarization is a means to attenuate the inherent violence of the world through both the establishment of a plurality of consanguineal units that are fractions of a single predatory body at the meta-human end, and of human bodies made from a predatory state of bodilesness at the infra-human level. *

* Manuscrit reçu en juillet 2008, accepté pour publication en avril 2009.

\section{NoTES}

The article was written during a post-doctorate at the Laboratoire d'anthropologie sociale (LAS) within the scope of the project "Arte, Imagem e Memória. Horizontes de uma Antropologia da Imagem e da Cogniçào ", coordinated by Carlos Fausto and Carlo Severi. I thank the 
Coordenação de Aperfeiçoamento de Pessoal de Ensino Superior (CAPES) for making my time in Paris possible, Philippe Descola for welcoming me at the LAS and Carlo Severi for supervising my research. Previous versions of this text were presented at the Séminaire d'anthropologie américaniste at the Maison des Sciences de l'Homme de Paris and the panel on Amazonian Themes at the Society for the Anthropology of Lowland South America congress in Oxford. I thank Jean-Pierre and Bonnie Chaumeil, and Laura Rival for the opportunity, as well as to the participants for their comments. I am especially grateful to Carlos Fausto for his suggestions, and to Francisco Queixalós, Emmanuel de Vienne, Oiara Bonilla, Jeremy Deturche, Pedro Cesarino, Joana Miller and Marc Brightman for their observations at various stages. Fieldwork among the Kanamari was financed by the Wenner-Gren Foundation for Anthropological Research, the Programa de Pós-Graduação em Antropologia Social (UFRJ/Museu Nacional), the Núcleo de Transformações Indígenas (NutiPRONEX), the Conselho Nacional de Pesquisa e Desenvolvimento (CNPq) and the Centro de Trabalho Indigenista (CTI).

1. The Kanamari number some 1,600 people spread out over a large area whose axis is the Juruá River, a tributary of the right bank of the Amazon. The Juruá's headwaters lie in the Ucayali highlands in Peru (where it is called Yuruá) from which it flows on a north-northeastern gradient, entering Brazil in the state of Acre and discharging into the right bank of the middle Amazon. The Kanamari are one of the few surviving Katukina-speaking peoples and they claim to have always inhabited the tributaries of both banks of the middle Juruá, in the Brazilian state of Amazonas, where most of them still live. Ethnographically, they are situated between Panoan speakers to the north and west (Kaxinawa, Marubo, Matis, Matses) and Arawan-speakers to the south and east (Kulina, Deni). In spite of the fact that most Kanamari still live on the tributaries of the Juruá, all of my fieldwork was carried out among the Kanamari who currently live in the upper Itaquaí River, which is not a part of the Juruá basin, but rather of the Javari, which is situated just to the north of it. These Kanamari started to migrate into the Itaquai in the mid-1930's, mostly escaping the encroachment of rubber tappers who began to occupy the tributaries of the left bank of the Juruá, where they had lived. A large part of the discussion that follows is based on how these Kanamari told me that they used to live in that area prior to the arrival of the Whites. I thus reconstruct a native model of society which, if it ever did exist, no longer does so, at least not in its specificities. Nonetheless, the type of relations described here continue to inform how the Kanamari live today, despite important differences - differences that can, in fact, be understood as transformations of this very model (Costa 2007). I have therefore opted to use the present tense in my discussion of the general aspects of the model, not only because of these evident continuities, but also because what I describe is a template and we have no way of knowing to what extent it ever represented actual, on the ground forms of social organization.

2. Various studies of the Melanesian person have made imaginative use of the mathematical theory of fractals in order to reconfigure relationships that constitute persons and those that link persons to others, in such a way as to overcome the opposition between parts and wholes, singular and plural (e.g. Strathern 1991; Wagner 1991). A fractal is a figure that reveals the same properties at different scales and in anthropology it has been evoked in order to reveal how persons are multiply constituted out of the same relationships that constitute wider units (e.g. lineages, clans). The person and these units are therefore self-similar reifications of certain relationships replicated at varying scales. In Melanesia, these relationships, or the terms that are put in relation, are often gendered, in that sense that it is relations between male and female properties that constrain the constitution of persons, however these be defined (Strathern 1988; Gell 1999). In Amazonia, as Descola (2001) has shown, gender relations are much less salient or paradigmatic, often being themselves constrained by (or subsumed under) another relation, that between predator and prey. With this caveat, the use of fractal theory by Melanesianists and the notion of multiple personhood has exerted a growing influence on recent descriptions of the Amazonian social milieu (e.g. Taylor 2000; Kelly 2001; Viveiros de Castro 2001; Fausto 2007). Although I make no effort to discuss the Kanamari in relation to the Melanesian ethnographies in which the notions of fractality and self-similarity were first employed, the Americanist literature that has been inspired by these studies were a constant source of ideas for the arguments 
that will follow. Ultimately, I hope that it will become evident how the Kanamari -warah reverberates with these theories, while nonetheless revealing its own particularities.

3. The word -warah is made into noun phrases of the inalienable or divalent type (Queixalós 2008). Such noun phrases can sometimes be case marked with -na. The Kanamari explained the use of -na to me as specifying a definite subject, whereas non-case marked constructions express a generic participant. In this way, tukuma-na-warah refers to the -warah of a specific person, pre-defined in discourse, whereas tukuma-warah is any human -warah; likewise, pok-na-warah means the -warah of a canoe that one has seen before, or knows to exist, rather than the -warah of any « canoe " or of the class " canoe ", which would be pok-warah. Although this does seem to hold in many instances, in practice I noticed much variation in the use of the case marker, with both marked and unmarked phrases being used interchangeably.

4. A thorough description and analysis of Kanamari subgroups, which would require taking into account the rituals that ensure interactions between them, is not the aim of this paper (see Costa 2007, pp. 75-88).

5. I have opted to reproduce a schematic map, based on another one that I drew in the field with the help of two Curassow-dyapa men. I cannot confidently vouch for the accuracy of the tributaries it represents. Official maps, produced by the Brazilian Institute of Geography and Statistics (IBGE), show a somewhat different hydrology for the Komaronhu (called São Vicente in Portuguese). Since I was unable to visit the Komaronhu and ask the Kanamari in situ about these differences, I have chosen to use the map drawn in the field, which shows how the Curassow-dyapa of the Itaquai depict the river in which their ancestors lived. The map is thus not to scale in the sense of our geography, but it reveals a Kanamari scale in which society and topography are isomorphic.

6. For the purposes of this article, "tributaries " denote affluents of the Juruá river, while " streams » refer to bodies of water that flow into tributaries. When I refer to " river basin » I generally mean one or any of the river basins of the tributaries of the Juruá, unless otherwise specified.

7. Readers familiar with the literature on Western Amazonia may have noticed how similar, in its formal aspects, the settlement pattern of Kanamari river basins is to the structure of the debt-peonage (aviamento) economy of rubber extraction (see Almeida 1992). The rubber economy depended on the existence of storehouses (barracões), owned by bosses (patrões), often established on larger river channels. The bosses supplied a workforce of rubber tappers (seringueiros) with material goods. The seringueiros set up more or less temporary camps no centro, i.e., deep in the forest, away from the larger channels and towards the concentration of Hevea trees on subsidiary rivers. Other authors have considered the important congruences between aviamento and native sociologies and cosmologies (Gow 1996; Carneiro da Cunha 1998). The similarity between the two forms of organization is more or less explicitly recognized by the Kanamari, but I must stress that the model I describe here corresponds to their view of how they lived prior to the arrival of the Whites. It is impossible, given the state of historical, archaeological and ethnographical knowledge of the Juruá, to know if this « traditional » model of Kanamari society is a retrojection of the structure of aviamento in which they participated during the first half of the twentieth century. From a Kanamari perspective, the congruence between their form of social organization and that of the rubber economy was a fortunate coincidence, which for a period enabled them to interact with the bosses while maintaining the scale of their society (see Costa 2007, pp. 96-107).

8. This is similar to the Kaxinawa, for whom souls and spirits are linked to formlessness, while «... the human condition rests on the conquest of a particular fixed form amidst a multiplicity of possible forms » (Lagrou 2007, p. 24).

9. The word tokodo means to take care by keeping fixed and stored in place, and not by carrying around what one takes care of. It seems to include the morpheme to-, which can mean « to reside » at a given place.

10. By « subject " I mean a person - as defined by the Kanamari - who, in a given context, retains intentionality, the capacity to act and the will or volition to make things happen. Subjects are those who interact with other subjects in a variety of ways. "Object ", on the other hand, is any person who, 
within a given context, has another act for them, surrendering their volition to one who makes things happen in spite of them or on their behalf. I should add that contextually defining " subject " and " object " is always a function of focusing on a specific relation, and one should not lose sight of the fact that persons, whether contextually a subject or an object, are themselves composed of subject and object parts that can reveal themselves in other relationships (see Fausto 2007).

11. Although I cannot here develop how the subgroup chief's supplementarity manifests itself, some of this capacity has already been suggested. We have seen, for example, that he is the precondition for the emergence of game through his knowledge of Jaguar-songs. The subgroup chiefs of the past are also described as excellent hunters, and their role in organizing rituals between subgroups made them into possible agents of actual predation/warfare (see Costa 2007, pp. 75-91). This predatory capacity was inscribed on the body, and former subgroup chiefs are always said to have been large and beautiful. One Kanamari man told me that former subgroup chiefs never grew old, and that they only died because of sorcery. They also wore different body ornaments - typically larger versions of those worn by non-chiefs, particularly the nasal crescent. Thus if the -warah is based on the replication of the same relations, its apprehension at different scales shows an accretion of potency between levels of body-owner in which the subgroup chief emerges as an " anomalous » version of his population (see Rodgers 2002, p. 115).

12. I capitalize "Jaguar » so as to distinguish these mythical beings and their corollaries from present-day homonyms. The Kanamari sometimes contrast the two by calling the former « old Jaguars " (Pidah kidak). Present-day jaguars have their origin in a myth in which they were created from the mud of a lake bed after the destruction of the old Jaguars. They are seen to be a pale residue of mythical Jaguars, for while they retain an impressive predatory capacity, they are no longer able to situate the world in and through their bodies.

13. I have elsewhere analyzed this and other myths of the Jaguar in greater detail (Costa 2007, chap. 4).

14. This is evidently only half of the story. A thorough consideration of the ways in which the -warah familiarizes its inverse would require an analysis of how the structure is apprehended from its other end - that is, it would have to account for what the -warah looks like from the perspective of souls and non-chiefs. In other words, it would be necessary to make explicit a particular way of being prey, which would reveal how the familiarization of souls and non-chiefs simultaneously enables the latter to pacify and domesticate the predatory potency of the body-owner at different levels. As other authors have shown, the position of prey and the submission that it entails does not always result in powerlessness, and being prey can be a means for controlling the predatory nature of others (see Bonilla 2007; Rival 2002). The ways in which, for example, non-chiefs continuously ensure that the chief feeds themthrough their labour in the large garden, and by bringing him game meat for redistribution during ritual events - are an evident counterpart to the cosmological transformation of predation into feeding. Furthermore, such an approach would reveal an essential aspect of familiarization that has been left out of the present analysis: its ambivalence and reversibility, as well as the impossibility of entirely neutralizing « the subjective potency of the other " (Fausto 1999, p. 949; see Costa 2007, chap. 2 and 4, for moments in which the stability of body-owners were overwhelmed by mobility and violence).

\section{REFERENCES CITED}

\section{Almeida Mauro}

1992 Rubber tappers of the upper Jurua river, Brazil. The making of a forest peasant economy, PhD dissertation, University of Cambridge, Cambridge.

\section{BONILla Oiara}

2007 Des proies si désirables. Soumission et prédation pour les Paumari d'Amazonie brésilienne, thesis, École des hautes études en sciences sociales, Paris. 
BrightMAN Marc

2007 Amerindian leadership in Guianese Amazonia, PhD dissertation, University of Cambridge, Cambridge.

Carneiro Da Cunha Manuela

1998 "Pontos de vista sobre a floresta amazônica: xamanismo e tradução », Mana, 4 (1), pp. 7-22.

\section{Costa Luiz}

2007 As faces do jaguar. Parentesco, história e mitologia entre os Kanamari da Amazônia ocidental, thesis, Museu Nacional, Rio de Janeiro.

Descola Philippe

2001 «The genres of gender: local models and global paradigms in the comparison of Amazonia and Melanesia ", in Thomas Gregor and Donald Tuzin (eds), Gender in Amazonia and Melanesia. An exploration of the comparative method, University of California Press, Berkley, pp. 91-114.

ERIKSON Philippe

1996 La griffe des aïeux. Marquage du corps et démarquages ethmiques chez les Matis d'Amazonie, Éditions Peeters, Paris.

Fausto Carlos

1999 "Of enemies and pets: warfare and shamanism in Amazonia », American Ethnologist, 26, pp. 933-956.

2007 "Feasting on people. Eating animals and humans in Amazonia », Current Anthropology, 48, pp. 497-530.

2008 "Donos demais: maestria e domínio na Amazônia », Mana, 14 (2), pp. 329-366.

GeLl Alfred

1998 Art and agency. An anthropological theory, University of Oxford Press, Oxford.

1999 "Strathernograms, or the semiotics of mixed metaphors », in Alfred Gell, The art of anthropology. Essays and diagrams, the Athlone Press, London, pp. 29-75.

Gow Peter

1991 Of mixed blood. Kinship and history in Peruvian Amazonia, University of Oxford Press, Oxford.

1996 " River people: shamanism and history in Amazonia », in Nicholas Thomas and Caroline Humphrey (eds), Shamanism, history and the state, Michigan University Press, Ann Arbor, pp. 90-113.

HeCKenBerger Michael

2005 The ecology of power. Culture, place and personhood in the Southern Amazon, A.D. 1000-2000, Routledge, Abingdon.

Kelly José Antonio

2001 "Fractalidade e troca de perspectivas », Mana , 7 (2), pp. 95-132. 
LAGROU Els 2007

A fluidez da forma: arte, alteridade e agência em uma sociedade Amazônica (Kaxinawa, Acre), Topbooks, Rio de Janeiro.

\section{McCallum Cecilia}

2001 Gender and sociality in Amazonia. How real people are made, Berg Books, Oxford.

\section{QueiXalós Francisco}

2008 «Grammatical relations in Katukina-Kanamari » [manuscript].

Rival Laura

2002 Trekking through history. The Huaorani of Amazonian Ecuador, Columbia University Press, New York.

\section{RIVIÈRE Peter}

1984 Individual and society in Guiana: a comparative study of Amerindian social organization, Cambridge University Press, Cambridge.

\section{RODGERS David}

2002 "A soma anômala: a questão do suplemento no xamanismo e menstruação ikpeng ", Mana, 8 (2), pp. 99-125.

\section{STRATHERn Marilyn}

1988 The gender of the gift. Problems with women and problems with society in Melanesia, University of California Press, Berkley.

1991 Partial connections, Rowans \& Littlefield, Savage MD.

TAYLOR Anne Christine

2000 "Le sexe de la proie. Représentations jivaro du lien du parenté », L'Hormme, 154-155, pp. 309-334.

2001 "Wives, pets and affines: marriage among the Jivaro », in Laura Rival and Neil Whitehead (eds), Beyond the visible and the material. The Amerindianization of society in the work of Peter Rivière, Oxford University Press, Oxford, pp. 45-56.

VilaçA Aparecida

2002 "Making kin out of others in Amazonia ", Journal of the Royal Anthropological Institute, (ns) 8, pp. 347-365.

2005 "Chronically unstable bodies: reflections on Amazonian corporalities », Journal of the Royal Anthropological Institute, (ns) 11, pp. 445-464.

\section{Viveiros De Castro Eduardo}

1998 "Cosmological deixis and Amerindian perspectivism », Journal of the Royal Anthropological Institute, (ns) 4, pp. 469-488.

2001 "GUT feelings about Amazonia: potential affinity and the construction of sociality », in Laura Rival and Neil Whitehead (eds), Beyond the visible and the material. The Amerindianization of society in the work of Peter Rivière, Oxford University Press, Oxford, pp. 19-43. 


\section{WAGNER Roy}

1991 "The fractal person », in Maurice Godelier and Marilyn Strathern (eds), Big men and great men. Personifications of power in Melanesia, Cambridge University Press, Cambridge, pp. 159-173. 